\title{
Disaster, displacement and justice: Powers and Faden's theory of social justice and the obligations of non-governmental organizations towards Internally Displaced Persons
}

\author{
Caroline Clarinval ${ }^{a}$, Matthew R. Hunt ${ }^{b}$ \\ a Institute of Biomedical Ethics, University of Zurich, Switzerland \\ b School for Physical and OccupationalTherapy, McGill University, and the Centre for Interdisciplinary Research in Rehabilitation. Montreal, Quebec
}

\begin{abstract}
Disasters have major impacts on populations, disrupting people's lives and exposing them to harm and, potentially, injustice. A range of actors, including national and international non-governmental organisations, provide assistance to victims of disasters. Initial disaster relief efforts primarily focus on saving lives. As the response progresses, efforts to promote recovery for individuals and communities affected by disaster become increasingly important. Given the heightened vulnerability and widespread needs of populations affected by disaster, choices must be made regarding which services and programs will be prioritized at each stage of the response. In consequence, questions of equity and justice arise related to these decisions, particularly as the acute crisis abates and a range of assistance programs aimed at promoting recovery is considered. The nature of these justice considerations and their implications for disaster response programs has received limited discussion in the literature. In this paper, we consider the potential contribution of Powers and Faden's theory of Social Justice for clarifying justice-based responsibilities of non-governmental organizations towards populations displaced within their own country by a disaster, and contrast it with the Basic Needs Approach widely used by humanitarian organizations. According to Powers and Faden, justice requires that a minimally sufficient level of well-being be secured for individuals who are systematically disadvantaged. We argue that this conception of social justice can help direct attention to diverse dimensions of well-being, and orient program planning in situations where non-governmental organizations work with internally displaced populations post the acute crisis of the disaster response.
\end{abstract}

Keywords: ethics, humanitarian action, internally displaced persons, social justice

\section{Introduction}

The United Nations Department of Humanitarian Affairs [1] defines disaster as "a serious disruption of the functioning of society, causing widespread human, material, or environmental losses, which exceed the ability of the affected society to cope using only its own resources.” Disasters can be caused by natural, technological, international, civil or political hazards [2|] ${ }^{1}$.

1 In this paper, we use the term "disaster" to refer to events that result from any of these causes.
Globally, natural or man-made disasters affect over 70 million people each year $[3,4]$. These disasters result in widespread displacement of populations. The International Federation of the Red Cross [4] estimates that in 2011, 16.4 million persons were refugees, 41.3 million were internally displaced persons (IDPs ${ }^{2}$ ) of whom 26.4 million were internally displaced due to conflict and 14.9 million as a result of natural disaster. An additional 15 million people were displaced due to large-scale constructions, such as dams and urban renewal projects. The number of IDPs fluctuates annually, mainly due to the occurrence of natural disasters. Specific data related to the frequency and extent of protracted displacement (i.e. those who were displaced for more than one year) is limited and constitutes a gap in knowledge [5], in many situations of long-standing political instability around the world populations have been displaced for decades [6].

Disasters, however, are by definition situations when local response and coping capacity is exceeded [2] and external assistance is required. In many settings of disaster, this aid will come from within the country. In other contexts, particularly in low and middle income countries, international and national non-governmental organizations (NGOs) play a key role in disaster response $^{3}$. NGOs may provide short-term relief efforts, including surge capacity to respond to an acute event, or participate in disaster response operations of longer duration. Where national and local governments are unable or, for a variety of reasons, unwilling to commit sufficient resources to ensure a minimal level of wellbeing for local populations, it can be argued that the international community has a moral obligation to come to the aid of these "distant strangers" [7]. While such moral claims have been contested [8], this moral-

2 Internally displaced persons (IDPs) are defined in the Guiding Principles on Internal Displacement as "persons or groups of persons who have been forced or obliged to flee or to leave their homes or places of habitual residence, in particular as a result of or in order to avoid the effects of armed conflict, situations of generalized violence, violations of human rights or natural or human made disasters, and who have not crossed an internationally recognized state border" [10].

3 Even in highly industrialized nations, support from other countries may be necessary to provide surge capacity for relief efforts following a disaster. 
impetus is a strong motivator for international humanitarian responses and is associated with the "humanitarian imperative" which is understood as a commitment to alleviate suffering wherever it can be found [9].

Disasters may result in populations fleeing areas most affected by the disaster, either crossing international frontiers (refugees) or moving within their country and settling in a camp or with host families (IDPs). In such circumstances, people's coping mechanisms are stretched, and may be exceeded. Affected populations are at elevated risk of becoming destitute and therefore dependent on external aid. International and national NGOs, alongside government agencies, provide aid and assistance to IDPs. Agencies may also assist host families and resident communities to strengthen their capacity to deal with the influx of IDPs draining local resources. Thus, the consequences of disasters are manifold and affect the capacity of displaced populations, as well as resident communities, to achieve a healthy and secure life. They may also disrupt their ability to continue their education or gain their livelihoods.

Typically, the obligations of NGOs towards IDPs affected by disaster have been conceived of as the responsibility to meet basic needs. The Basic Needs Approach (BNA) as described by Streeten [11], aims to draw attention to designing political systems that ensure that populations have access to those resources that are "universally needed (water, food, houses, equipment, production systems, schools, hospitals, community infrastructure)" and represent "a necessity for a fundamental life function like physical survival, or participating in the community as a citizen, worker or parent" [12]. As such, BNA focuses on requirements for "the opportunity for a full life" and does not merely aim to provide material commodities that are lacking [12].

Many humanitarian actors, however, while appealing to BNA, appear to interpret the concept of meeting basic needs of a population in precisely this minimalist and material way. Thus there appears to be a gap between the theory of BNA and how it is applied-by humanitarian NGOs. In practice, many organizations operate by first assessing the situation on the ground and then responding to identified survival and material needs which ultimately results in programs that focus on saving lives and replacing lost assets. A minimalist BNA view does not draw attention to other basic needs such as community participation, self-determination, respect, engagement and empowerment. This distinction is illustrated by use of standardized relief kits that are prepared to optimize response times for emergency situations. For example, food rations distributed by the World Food Program are similar across many countries and do not necessarily correspond to local food habits. While these kits address the primary objective of ensuring adequate caloric intake for affected populations, they may increase the sense of rupture for beneficiaries if their contents are unfamiliar and foreign to them [13]. This example suggests that other dimensions of well-being beyond bare survival are pertinent even in acute relief efforts. While rapid response to crises is of vital importance, questions ought still to be asked regarding how disaster response could promote the well-being of aid recipients.

Attention to other dimensions of well-being becomes increasingly important once the disaster situation has begun to stabilize. As life-saving efforts shift to the promotion of recovery, a minimalist BNA is insufficient to account for all the needs of local populations. However the BNA may continue to be employed as primary frame for project planning and evaluation.

The minimalist approach reflects a conception of BNA as the "bundle of goods" needed by individuals affected by crisis, rather than the "full life objective" interpretation of BNA [13]. As such, the BNA as applied in the humanitarian context often fails to address the political dimensions, or other determinants that influence a situation of precarity and capacity for recovery. Given these limitations, it might be argued that what is needed is the adoption of the more encompassing version of BNA to guide disaster response efforts. Such a proposal could include the continued use of a minimalist BNA during an acute crisis, and then an increasingly encompassing understanding of BNA as the response progresses and the context stabilizes. A concern related to this approach would be the risk of confusion, especially as the minimalist approach to BNA is well entrenched in the culture, vocabulary and policies of humanitarian organizations. The encompassing version of BNA may also be more difficult to apply as it lacks a structured approach for examining the elements that make up the "full-life objective" thus rendering it more difficult to apply in practice. An alternate course of action is to identify other normative accounts that would provide guidance that goes beyond the minimalist BNA and that would be better suited to support operational choices in disaster response. It is this latter approach that we adopt here.

We examine in this paper the potential contribution of Powers and Faden's theory of Social Justice [14], focusing on sufficiency of well-being, for orienting program planning for NGOs providing assistance to IDPs in the post-acute phase of a crisis, and how it might draw attention to important features of justice and injustice for displaced populations. We have selected Powers and Faden's theory of social justice from amongst other possible options due to several aspects of their theory that appear salutary for the goal of providing an account of justice considerations in disaster response after the acute relief phase ${ }^{4}$. These attributes include clear articulation of dimensions of well-being, an ac-

4 We acknowledge that other conceptual accounts might also be applied to the analysis of social justice for IDPs affected by disaster. Approaches such as those of Nussbaum [17], Nussbaum and Sen [18] or Daniels [19] could be used to identify responsibilities of humanitarian and governmental actors. We have elected to use Powers and Faden's theory for the reasons stated in the text. 
count of how systematic injustice relates to exposure to harm, and attention to cascading effects. The notion of cascading effects emphasises the interrelationship between different dimensions of well-being and how deterioration in one area will likely lead to deterioration in other areas. This relationship between elements of well-being is very pertinent for disaster response planning. In addition, while humanitarian organisations are rarely able to address root causes of differential vulnerability to disaster, their programs might further exacerbate the challenges faced by affected populations. For example, Anderson [15] highlights, that "even when it is effective in doing what is intended to do to save lives or promote development, aid too often also feeds into, reinforces and prolongs conflicts”. Adopting an explicit social justice lens promotes attention to issues beyond mere basic needs and encourages humanitarian agencies to attend to the interrelationships among dimensions of well-being, and especially those having cascading effects on well-being. To illustrate our analysis, we present a fictive case.

\section{Case: IDP camp}

Fleeing fighting, drought and general insecurity, 5000 individuals are arriving each day to seek refuge in an IDP camp. The camp is situated in the vicinity of a regional mid-size town with 50000 inhabitants. There is no official camp management and thus far the community elders have been in charge of allocating space for newly arrived IDPs within the camp. The local and regional governments are overwhelmed by the influx of IDPs and have asked national and international NGOs to help support the displaced population. About 100000 people have already settled in the camp and are receiving assistance from NGOs whose operations focus on the provision of goods and services such as food, potable water, shelter, sanitation, healthcare and education. Though government authorities allocated the site for the camp, its capacity has already been exceeded. However, the inhabitants are unwilling to relocate elsewhere and new IDPs continue to arrive. The camp population is mainly constituted of women, along with children and the elderly. Most men have stayed behind to secure their assets or have joined fighting forces.

The administrative, security and healthcare resources of the neighbouring town are being stretched to their limit by the presence of the IDP camp. On the other hand, the economic activity of the town is flourishing and its markets are booming. The IDPs have freedom of movement and access to markets to trade their personal and relief goods. The local town authorities are overwhelmed and unable to provide security to the IDP population. The national and international NGOs are not in a position to guarantee and enforce safety. Malnutrition rates are stabilizing and food assistance is being provided at 1800 kilocalories per day. The minimum access to 15 litres of water per person per day [16] is not entirely met. Insufficient shelters are available to house all new arrivals and multiple families have to co-habit. Health care structures within the town and in the camp are also overwhelmed. Access to basic education for children is limited due to lack of infrastructure and teachers. There are few agencies on the ground and those that are present struggle due to limited human, material and financial resources to cope with the many needs of the IDPs.

\section{Responding to basic needs in disasters}

This case suggests the degree and breadth of needs frequently experienced by populations displaced following armed conflict or natural disaster. In such circumstances, NGOs and other actors provide a range of goods and services to affected populations. Many populations experience prolonged displacement - some for years or decades - and their needs typically evolve from acute survival to those related to ensuring a minimal level of well-being, including respect and the capacity for self-determination. The rationales expressed by NGOs for relief projects addressing needs of IDPs are often still framed by the concept of BNA or, more broadly, in relation to human rights.

Some commentators express the justification for humanitarian response in relation to rights, emphasising the right to life, the right to food, the right to basic health care or the right to physical well-being as fundamental and inviolable human rights [20-23]. We acknowledge the importance of rights-based justifications, however a prolonged discussion of rights based discourse is beyond the scope of this paper. Rights based accounts are typically used to motivate and justify relief activities but do not typically specify the types of responses that ought to be provided. In addition, rights based arguments are often used to justify basic needs approaches and are therefore closely related to BNA in practice. For these reasons, and since BNA is the dominant approach in the field, we will focus on BNA in our analysis and consider how it relates to a social justice approach.

Severe disasters have wide-ranging and significant impacts on displaced individuals, especially in contexts where individuals were already poor and public institutions weak. Populations affected by disaster have been described as among the world's most vulnerable populations [24] and are at increased risk of threats, oppression, domination and subordination. Individuals and populations who were impoverished or marginalized prior to the disaster are especially likely to be exposed to such phenomena [25]. However, all populations displaced by a major disaster can be considered at risk of being systematically disadvantaged. As discussed earlier, the BNA aims to ensure 
survival by meeting elementary bodily needs [26]. Prioritizing meeting people's survival and elementary bodily needs is morally responsible in the acute crisis phase. Yet, people living in camps for extended periods may remain systematically disadvantaged over several years. The BNA provides little guidance for addressing needs of displaced populations to live a minimally decent life once elementary bodily needs (ibid.) are met.

The scale and scope of needs resulting from a disaster can result in vexing decisions related to the allocation of limited humanitarian aid resources, and humanitarian actors face ethically challenging choices [27]. Some aid workers and managers report that such decisions become more frequent as the acuity of the situation abates and a range of programs are considered which each respond to important community needs [29]. These struggles may be accentuated when there is a lack of criteria or guidance for making these choices. Powers and Faden's theory of sufficiency of well-being [14] draws attention to the range of considerations that warrant consideration in evaluating and selecting programs to implement in situations where immediate survival needs have been met. Powers and Faden's theory of sufficiency of well-being argues that other aspects of well-being besides the basic needs for survival are necessary for human flourishing, and identifies six dimensions of well-being: health, personal security, reasoning, respect, attachment and self-determination. They argue [14] that "some injustices that involve harms to health involve different, additionally salient harms to other dimensions of well-being” beyond those impacting upon elementary bodily needs and which also require attention from the perspective of social justice [14]. Powers and Faden [14] also assert that "a unified theory of well-being and its relation to the primary social determinants requires attention to the causal pathways that influence the outcomes that matter centrally to justice” and [14] describe how systematic disadvantage has a cascading effect; being unable to meet a sufficient level of well-being in one dimension could jeopardize the ability to meet a sufficient level of well-being in other dimensions and compromise one's ability to live a minimally decent life. For instance, "the initial negative effect of some aspect of the social structure on one essential dimension of wellbeing, in turn, becomes the primary social determinant of an adverse effect on another dimension of well-being. The two effects interact to magnify and reinforce the negative effects on both, and the result can be a cluster of effects on multiple dimensions of well-being such that more than one dimension is systematically brought below a level of sufficiency" [14].

As described by Loescher et al [29] "the majority of IDPs are in a state of extended and chronic displacement" and multiple facets of their well-being are affected. As illustrated in the case presented above, populations that have had to flee their homes are likely to experience distress due to losing or being separated from family members, as well as losing their assets and sources of income. The impact of the disaster event, which led them to flee, will lead to impacts that have cascading effects amongst their personal security, their health including bodily harm or psychological distress, as well as their attachments in situations where families are separated. These populations are likely to become dependent on external aid to see their basic needs covered. Given the situation of armed conflict and insecurity that they have fled, they may remain in displacement for prolonged periods and are thus at risk of being systematically disadvantaged. To address such a situation, humanitarian actors would benefit from adopting a sufficiency of well-being approach to assessing, designing and implementing aid programs and to identify possible cascading effects between dimensions of well-being. In this way, humanitarian actors will be supported to identify the set of needs - extending beyond mere basic needs - that are necessary to ensure that victims of disaster are less systematically disadvantaged and able to live minimally decent lives.

In the following sections, we discuss how the six dimensions of well-being identified by Powers and Faden - health, personal security, reasoning, respect, attachment and self-determination - can be applied to the context of an IDP camp to address systematic disadvantage and promote well-being to ensure a minimally decent life for displaced victims of disasters.

\section{Health}

In their theory of sufficiency of well-being, Powers and Faden [14] define the concept of health more restrictively than the World Health Organization (WHO), arguing that the WHO's definition of health "conflates virtually all elements of human development under a single rubric and thereby makes almost any deficit of well-being into a health deficit". Powers and Faden define health as a biological or organic functioning of the body, stating that [14]:

“... it reflects a moral concern with the rich and diverse set of considerations and characteristics of public health and clinical medicine, including premature mortality and preventable morbidity, malnutrition, pain, loss of mobility, mental health, the biological basis of behaviour, reproduction (and its control), and sexual functioning... Health is of independent (although not exclusive) moral concern when threatened by war, violence, environmental hazards, consumer products, and natural disasters."

In the case of an IDP camp where immediate survival needs have been met, health-oriented activities will first be focused on the provision of primary health care, such as the treatment of communicable diseases. As resources allow, health promotion programs including 
those focused on vaccination, maternal and child health, as well as sanitation and hygiene, may be implemented in addition to basic curative care. Once primary healthcare infrastructure is established in the camp and a referral system set up, humanitarian aid workers are able to treat or refer a wide range of conditions. These health-related interventions, as well as those focused on survival needs such as sufficient food, safe water and shelter, are a central component of disaster response initiatives.

\section{Personal security}

Many IDP camps are relatively unsafe environments, and IDPs are frequently exposed to risks during a perilous journey to reach them. Security is also rendered more precarious since displacement disrupts the family structure; women, children and the elderly tend to be the largest demographic groups in IDP camps, as the men often stay home guarding their goods or engaging in conflict. The statistics about security for IDPs are stark: The Unites States General Accounting Office [30] reported that IDPs are subject to direct physical attack or threat in $90 \%$ of countries and at risk of forced migration in $58 \%$. Female IDPs are at risk of sexual assault in $46 \%$ of nations [30].

In contrast to refugees, IDPs have fewer legal protections as their status is not widely recognized under customary and international law, and the Geneva Conventions may be difficult to apply [2]. In this context, responsibility to protect IDPs lies with governments as inscribed in national constitutions. IDPs are particularly at risk of harm in situations of armed conflict. This risk of harm may be associated with the targeting of civilians by belligerent forces engaged in active fighting. Disasters may also lead to situations of widespread insecurity and lawlessness.

For Powers and Faden [14], "injustices involving assault, enslavement, degradation, and rape also violate any minimal notion of respect for persons as moral equals" and, as such, ought to be addressed by the national authorities. However, in situations of civil war and other disasters, ensuring security for IDPs will be difficult if not impossible, even where governments are committed to achieving this objective. Governments often fall short of ensuring the security of IDPs in situations of crisis or disasters due to overwhelming needs, breakdown of infrastructure, and a lack of law enforcement. Other actors, such as the International Committee of the Red Cross (ICRC) and the United Nations High Commissioner for Refugees (UNHCR), seek to promote respect for the rights and protection of IDPs though cannot directly ensure their security. Protection in this sense emphasises efforts to support and enhance respect of international humanitarian law (IHL) and human rights by all parties to a conflict [31]. While these agencies focus on protecting rights rather than directly enforcing security, the design of aid programs by these actors, as well as NGOs, can take account of how interventions might promote the security of beneficiaries, and contribute to minimizing and mitigating possible security risks for IDPs.

Though humanitarian NGOs are unable to enforce security per se, they have a responsibility to promote it, and can make program decisions that increase security of IDPs. In particular, they ought to ensure that their programs do not expose already vulnerable populations to additional risks. For example, distributing fuelefficient stoves can reduce the risk of rape since women leave the camp less frequently to search for wood and are less exposed to sexual assault by fighting groups. However, women must still leave the camps to pursue income-generating activities and might also be exposed to rape inside the camp. Thus, although the security impact of the stove program is limited in reach, such a program can contribute to the security dimension of well-being. According to Powers and Faden's model, it is necessary to consider the effects that providing for one need or dimension of well-being will have on other dimensions. In this case providing fuel-efficient stoves is likely to have a protective effect on health insofar as women are less exposed to the pulmonary health impact of inhaling wood smoke, as well as improved personal security. Such considerations are of paramount importance as sexual and gender-based violence represent "one of the most pervasive violations of the rights of women and girls during armed conflict and displacement" [5].

Aid organizations have a duty to ensure that their programs foster a safer environment, take personal security of beneficiaries seriously, and tailor their programs so as to promote personal security wherever possible. A commitment that aid should not further exacerbate the crisis or result in additional harm to the population has been endorsed by humanitarian actors as the primum non nocere (do-no-harm) principle. As stated by Anderson [5], "it is a moral and logical fallacy to conclude that because aid can do harm, a decision not to give aid would do no harm. In reality, a decision to withhold aid from people in need would have unconscionable negative ramifications." Yet, to address the security dimension of well-being, programs ought to deploy measures taken to prevent harm for IDPs particularly as they are likely to have a cascading effect on the other dimensions of well-being.

\section{Reasoning}

Powers and Faden associate reasoning with Aristotle's conceptualization of "theoretical reasoning skills aiding us in answering empirical questions and forming our understanding of what there is", as well as "skills of practical deliberation [which] aid us in deciding what we ought to do or how we ought to live" [14]. The concept of reasoning thus exceeds the focus on access to education endorsed by treaties such as the International Covenant on Economic, Social and Cultural Rights [32], the Declaration of Alma-Ata (1978) [33], 
the Universal Declaration of Human Rights (1948) [34], and other customary laws such as the Guiding Principles on Internal Displacement [10]. The dimension of reasoning not only supposes that people have the right and the ability to access schools and are granted the right of freedom of speech and expression, it also refers to the development and practice of a set of logic skills. Ensuring that people have the ability to improve their theoretical as well as practical reasoning skills contributes to people's ability for self-determination [14]. With this dual purpose in mind, aid organizations should promote an environment in which a) education plays a fundamental role as enshrined in several sources of law, ${ }^{3}$ b) their educational programs provide the required tools to allow students to reason, and c) beneficiaries can take part in decision-making through participatory initiatives. Including IDPs in the planning, design and implementation of programs will help ensure that these programs are well aligned to their needs and objectives. Participation in these processes will have the additional benefit of supporting reasoning skills.

Promoting reasoning skills might be particularly important for developing IDPs' abilities to plan their return home and to restore their lives and livelihoods. Reasoning skills are crucial insofar as they support IDPs to plan, and possibly reconceive, their lives after displacement and to restart their income generating activities. As a result of their situation of displacement, IDPs require extensive support from local authorities and the humanitarian aid community. To support the development and use of reasoning skills by IDPs, humanitarian actors, particularly those engaging in education programs, should integrate this notion into their programs with the aim to support the IDPs in their process of preparing to restore their lives and renew their livelihoods upon return.

\section{Respect}

Powers and Faden [14] assert that "both lack of respect and not being respected by others are assaults upon the status of the person as a morally worthy agent, deserving of and entitled to treatment as an equal." They argue "there are many ways in which that failure of respect contingently undermines self-respect ... Well-being of individuals is often tied to the well-being of groups. Respect for individuals is often a function of respect for the groups with which they are identified." This consideration can be associated with considerations of respect for communities, including local traditions, values and leadership structures. The principle of respect for communities has received attention in the literatures of public health ethics and research ethics $[35,36]$. Respecting local culture is identified as a re-

5 Art. 13 of the International Covenant on Economic, Social and Cultural Rights (ICESCR, 1976), Art. 19 and Art. 26 of the Universal Declaration of Human Rights (UDHR, 1948) Principle 23 of the Guiding Principles on Internal Displacement. sponsibility of humanitarian actors in the Code of Conduct for the International Red Cross and Red Crescent Movement and NGOs in Disaster Relief (1995) [37]. It is also consistent with the Banjul Charter, which is the African Charter on Human and Peoples" Rights (1981) [38]. The charter states that "the promotion and protection of moral and traditional values recognized by the community shall be the duty of the State". Despite a commitment to respect community values, it is often unclear how respect for culture ought to be implemented in global health activities, and disaster response efforts in particular, and how this principle ought to be balanced with other concerns including respect for human rights.

Displacement exposes IDPs to the risks of being harmed, disrespected and even humiliated. This situation is compounded where social structures have broken down. Unfortunately, humanitarian actors have limited power to address disrespect expressed by others. As for the promotion of security discussed earlier, they can contribute to establishing a respectful environment and ensure that their programs promote the respect of local cultures and preferences in as far as they are consistent with agreed international human rights and other obligations of NGOs. One implication of a concern for respect is that humanitarian actors ought to gear their efforts to not only provide sufficient but also culturally appropriate shelter, food and hygiene items, and facilities. For example, sanitation facilities and latrines should be set up in a fashion that respects local practices. This should be done not just for the instrumental purpose of promoting the use of these facilities, but as an act of respect for community traditions. In addition, NGOs could provide a platform for discussion where IDPs are invited to share their cultural concerns and contextual particularities with the humanitarian actors. In doing so, it is important to gather a comprehensive vision of the requirements of all IDPs, including women and elderly. Where the IDPs come from different or less homogeneous communities, efforts should be extended to hear from all groups and sub-groups.

\section{Attachment}

According to Powers and Faden [14], the "formation of bonds of attachment is one of the most central dimensions of human well-being." However, disasters often rupture family ties. The International Commission on Missing Persons (2012) [39] reports that about 150000 persons go missing every year due to natural or manmade disasters. Several agencies and governments engage in reconnecting families separated by disaster. For Powers and Faden [14], the concept of attachment goes beyond this notion of missing persons, and includes bonds such as friendship and love in their most intimate expression.

In the case of the IDP camp, humanitarian actors may support activities to locate the missing and to reunite 
families. They will also seek to support attachment. Humanitarian agencies are likely to pay particular attention to bonding in feeding centres when treating severely and moderately malnourished children. In such cases, healthcare personnel seek to promote the bonds between the mother, grandmother or caregiver, and the malnourished child. Such examples demonstrate that promoting attachment may not only be an important but also a life-saving measure. The structure and organization of the camp, including efforts to avoid overcrowding and having multiple families in the same shelter, can also promote attachment and avoid strain on families. While it is very difficult to promote attachment in the context of an acute humanitarian crisis, humanitarian aid workers should be attentive for occasions where attachment can be promoted. As the emergency abates, this goal may be increasing feasible, including in the context of restoring family ties.

\section{Self-determination}

Powers and Faden [14] underline that "people who live from meal to meal; who do not know if tomorrow there will be food for themselves or their children; who are dying of exposure, starvation, or exhaustion are not positioned to be self-determining in any meaningful respect.” The authors highlight that self-determination is an essential dimension of well-being and rests on views that it is important to be able to have some control and decision-making capacity over what one wants to do and become. Life in an IDP camp is clearly not an environment that promotes self-determination. Rather, IDPs typically have little control or opportunity to make decisions for themselves. They depend on external aid and cannot decide on the type of assistance they need or will be offered. They have little opportunity to satisfy the condition "that our lives be shaped at least in part by our choices, informed by our values and interests" [14].

Recognizing the importance of self-determination, humanitarian actors can seek to enhance opportunities for its expression. Consultation and participatory approaches can provide avenues for self-determination of IDPs. Self-determination is particularly crucial when IDPs are planning to return home. Returnees should be involved in restoring and shaping their lives, and agencies are tasked to continue engaging and empowering returnees during this process. When returnees return to their homes and are about to restart their livelihoods, humanitarian actors should promote the agency of IDPs to decide for themselves regarding the type of income generating activity they would like to engage in. Assistance programs should be guided by the priorities and preferences of returnees. After the Indian Ocean Tsunami, the British Red Cross (BRCS) supported several villages in Sri Lanka by providing cash grants [40] to enable returnees to make choices about how to restore their livelihoods in a sustainable and effective manner and thus promoting their recovery and inde- pendence from external aid [41]. The importance of fostering self-determination in such contexts can promote the dignity and confidence of returnees.

\section{Opportunities and limitations for this approach in practice}

Many of the examples and actions that we have associated with the theory of social justice are regularly enacted by humanitarian actors. Drawing upon Powers and Faden's theory of social justice in the context of humanitarian action can encourage humanitarian actors to further expand these activities and provides a conceptual frame that better reflects post-acute disaster response. This approach places emphasis on important considerations of well-being that are not highlighted by the basic needs approach. Thus, Powers and Faden's theory can provide humanitarian actors with a different lens through which to assess what ought to be met for IDPs. By including a focus on areas such as reasoning, respect, attachment and self-determination, this model supports humanitarian aid workers to broaden their needs assessments and design aid programs in the post-acute crisis phase that are more comprehensive than ones that follow a narrow view of meeting basic needs to ensure survival and replace lost assets.

By addressing the six dimensions of well-being, humanitarian actors are more likely to design programs that can help IDPs achieve a level of sufficiency of wellbeing during their displacement and upon return to their homes. However, a major challenge is that this approach may require a mid to long-term planning cycle. Unfortunately, many aid agencies are only able to secure funds for a period of one year or less due to the structure of funding programs. Short-term funding schemes are unfavourable to sustain programs that aim to promote a sufficient level of well-being when IDPs experience prolonged displacement. In addition, there are frequent changes among humanitarian actors and multiple agencies may care for the same IDP population over a given period of time. This level of high turnover amongst humanitarian actors, and their short term planning and funding schemes, will make interventions that are consistent with the theory of social justice more difficult to implement unless greater cooperation and agreement is achieved to adopt and promote this approach.

An important limitation to applying this theory in disaster response is that while drawing attention to different types of needs and their interrelations, it does not provide an explicit account of how to prioritize between competing options for program planning and selection. In practice, many NGOs have expertise and mandates that focus on certain dimensions of wellbeing (e.g. in health). Powers and Faden's theory suggests that programs focusing on health should at least 
pay attention to other areas of well-being, including potential impacts of their activities on other dimensions. The emphasis on cascading effects does suggest one way to prioritize between possible interventions: "in some cases it is conceivable that sufficiency of some dimensions of well-being (e.g. health) may be promoted best by attention to other dimension (e.g. reasoning development). In such cases, the answer to which inequalities are most urgent to address may be that we should give priority to addressing inequalities in those social determinants in which the potential adverse effects on more dimensions of well-being are at stake." [14]. While this insight will be helpful in some allocation decisions, Power and Faden's theory does not set out to provide ordinal rankings of the dimensions. It does, however, usefully expand the range of what is typically considered under the minimalist BNA approach and can thus help inform prioritization efforts by promoting attention to a wider array of relevant concerns.

A further challenge of applying this theory remains the difficulty to define a set of indicators to measure levels of sufficiency in the context of humanitarian action across these domains. If national and international NGOs are unable to develop indicators, it will be a challenge to monitor and evaluate the impact of programs. Given the nature of the dimensions (for example, in reasoning) indicators are unlikely to be easily quantifiable. While national and international NGOs continue assessing and addressing the basic needs in terms of water, sanitation, food, shelter, health care and education of IDPs living in camps, they should seek to incorporate considerations related to the other dimensions of well-being and establish indicators for each of the dimensions of well-being. For example, to measure the impact attachment has in a feeding centre, a possible indicator could be the number of children that are being cared for by their mothers, siblings or someone else from their family, and who could be successfully discharged from the nutrition programs into the care of their family members.

Explicitly conceptualizing humanitarian assistance for IDPs as seeking to promote social justice can suggest new opportunities to meet a level of sufficiency of well-being for displaced populations. Its application, however, requires the commitment of humanitarian actors and donors alike to implement programs that are consistent with a social justice approach in such contexts. Inevitably there will be situations in which these dimensions are difficult to achieve, but they should at least be considered during needs assessment and while designing programmes. Whether the preconditions to implement such measures are met in their totality or not should not prevent humanitarian actors from engaging in discussion of how these objectives could be promoted in their programs.

\section{Conclusion: Promoting well-being}

The theory of sufficiency of well-being proposed by Powers and Faden helps to draw attention to the wide range of features that contribute to a minimum level of well-being for displaced persons. This perspective focuses attention on social justice concerns beyond the provision of mere elementary physical needs. IDPs, particularly those living for extended periods of time in camps, will benefit from programs that are designed to assist individuals achieve sufficient levels of well-being in each of the six dimensions whilst having their basic needs met. Addressing these dimensions of well-being will promote the goal that victims of disasters are able to live minimally decent lives during displacement and upon return to their homes. Powers and Faden's theory provides a useful conceptual account of the range of considerations that are pertinent for IDPs in the postacute disaster phase, including attention to diverse facets of well-being and identification of cascading effects between them, and concern for systematic disadvantage.

Funding statement: This work was supported by the Käthe-Zingg-Schwichtenberg-Fonds (KZS 01/12). Matthew Hunt is supported by a Research Scholar Award from the Fonds de Recherche du Québec Santé.

Acknowledgments: We would like to express our deepest gratitude to Philippe Calain, Stéphanie Dagron, Carina Fourie, Agomoni Ganguli-Mitra, and Beat Schweizer for their helpful comments on earlier versions of this manuscript. Discussions with Zümrüt Alpinar, Nikola Biller-Andorno, Tanja Krones, Annette Rid and Verina Wild helped advance our thinking around these issues.

\section{Conflict of interest: none.}

\section{Résumé}

Les catastrophes ont des impacts majeurs sur les populations, perturbant la vie des gens et les exposant à subir des préjudices, et éventuellement de l'injustice. Un ensemble d'acteurs, comprenant les organisations non-gouvernementales nationales et internationales fournit une assistance aux victimes de catastrophes. Les premiers efforts de secours en cas de catastrophe visent principalement à sauver des vies. Au fur et à mesure que l'intervention progresse, les efforts visant à promouvoir le rétablissement des personnes et communautés touchées par des catastrophes gagnent en importance. Compte tenu de la vulnérabilité accrue et des besoins étendus des populations touchées par des catastrophes, des choix doivent être faits en ce qui concerne les services et les programmes à chaque étape de l'intervention. En conséquence, des questions d'équité et de justice se posent en relation avec les décisions prises, d'autant plus que la crise aiguë s'apaise et que des programmes d'aide visant à promouvoir le 
rétablissement des populations sont déployés. Ces considérations de justice et de leurs implications pour les interventions en cas de catastrophe n'ont reçu qu'une attention limitée dans la littérature. Dans cet article, nous considérons l'éventuelle contribution de la théorie de Powers et Faden en termes de justice sociale pour clarifier les responsabilités fondées sur la justice des organisations non gouvernementales en faveur des populations déplacées dans leur propre pays par une catastrophe, et nous la comparons à la stratégie des besoins de base largement utilisée par les organisations humanitaires. Selon Powers et Faden, la justice exige qu'un niveau minimum suffisant de bien-être soit assuré pour les personnes qui sont systématiquement désavantagées. Nous soutenons que cette conception de la justice sociale peut aider à attirer l'attention sur les diverses dimensions du bien-être, et à orienter la planification des programmes dans des situations où les organisations non gouvernementales travaillent avec les populations déplacées après l'intervention de la crise aiguë en cas de catastrophe.

\section{Zusammenfassung}

Katastrophen haben erhebliche Auswirkungen auf betroffene Populationen. Sie erschweren ihnen das Leben, beeinträchtigen sie und setzen sie möglicherweise auch Ungerechtigkeiten aus. Eine Reihe von Akteuren, einschliesslich der nationalen und internationalen nicht-staatlichen Hilfsorganisationen unterstützen Opfer von Katastrophen. Katastrophenhilfe zielt in erster Linie auf die Rettung von Leben ab. Danach werden Hilfsprogramme oft jedoch weiter ausgebaut, um den Wiederaufbau zu fördern, damit Menschen und ihre Gemeinschaften unterstützt werden können. Angesichts der erhöhten Verletzlichkeit und der grossen Bedürfnisse der Betroffenen müssen Entscheidungen getroffen werden um Programme zu priorisieren. Sobald die akute Krise nachlässt, wird eine Reihe von Hilfsprogrammen zum Wiederaufbau gefördert, wobei sich Fragen der Gleichheit und der Gerechtigkeit stellen. Gerechtigkeitsüberlegungen im Kontext der Katastrophenhilfe hat zurzeit begrenzte Aufmerksamkeit in der Literatur erhalten. In diesem Artikel wenden wir die Theorie der sozialen Gerechtigkeit der Autoren Powers und Faden zur Klärung von Gerechtigkeits-basierten Fragen an in Bezug auf die Unterstützung der Hilfsorganisationen für Vertriebene. Diese Theorie der sozialen Gerechtigkeit vergleichen wir mit der allgemein angewandten Theorie der Grundbedürfnisse. Nach Powers und Faden fordert Gerechtigkeit, dass ein Minimum an Wohlbefinden für Menschen, die systematisch benachteiligt sind, gesichert werden muss. Wir prüfen, ob dieses Konzept der sozialen Gerechtigkeit der Programmplanung der Hilfsorganisationen dient und ob es die verschiedenen Dimensionen des Wohls der Vertriebenen nach der akuten Krise stützen kann.

\section{Correspondence}

Caroline Clarinval MPH

Institute of Biomedical Ethics

University of Zurich

Pestalozzistrasse 24

$\mathrm{CH}-8032$ Zurich

Tel: 0041446345724

E-Mail: caroline.clarinval[at]ethik.uzh.ch

Manuscript submitted: 10.9 .2013

Revisions submitted: 12.12.2013

Accepted: 17.12.2013

\section{References}

1. United Nations Department of Humanitarian Affairs. Internationally Agreed Glossary of Basic Terms Related to Disaster Management. Geneva: United Nations; 1992.

2. Coppola DP. Introduction to International Disaster Management. Burlington: Butterworth-Heinemann Elsevier; 2007. p. 39-110.

3. UNHCR. Ten Years of Statistics [Internet]. 2010 [cited 2014 Apr 13]. Available from: http://www.unhcr.org/4ef9cc9c9.html

4. IFRC. Focus on forced migration and displacement [Internet]. 2012 [cited 2014 Apr 13]. Geneva; 2012 p. 15, 17. Available from: http:// www.ifrc.org/en/publications-and-reports/world-disasters-report/ world-disasters-report-2012---focus-on-forced-migration-and-displacement/

5. IDMC. Global estimates 2011 People displaced by natural hazardinduced disasters [Internet]. 2012 [cited 2014 Apr 13]. Available from: http://www.unhcr.org/50f95fcb9.html

6. Couldrey M. Herson M. Forced Migration review. Forced Migr. Rev. [Internet]. 2009;3 [cited 2014 Apr 13]. Available from: http://www. fmreview.org/FMRpdfs/FMR33/FMR33.pdf

7. Singer P. Famine, Affluence, and Morality. Philos. Public Aff. [Internet]. 1972; 1(3): 229-43 [cited 2014 Apr 13]. Available from: http:// philosophyfaculty.ucsd.edu/faculty/rarneson/SINGERFamineAffluenceandMorality.pdf

8. Goodin RE. Utilitarianism as a public philosophy. Cambridge: Cambridge University Press; 1995. p. 3-27.

9. Pictet J. The Fundamental Principles of the Red Cross: A Commentary. Geneva: Henri Dunant Institute; 1979.

10. OCHA. Guiding Principles on Internal Displacement [Internet]. UNHCR, editor. UNHCR; 2001 [cited 2014 Apr 13]. Available from: http://www.unhcr.org/43ce1 cff2.html

11. Streeten P. First Things First: Meeting Basic Human Needs in the Developing Countries. Washington: Oxford University Press; 1981. p. 3

12. Reader S. Does a Basic Needs Approach Need Capabilities? J. Polit. Philos. Sep. 2006; 14(3).

13. Cullen Dunn E. A gift from the American people. Iowa Review. 2012;42 (2):37-48.

14. Powers M, Faden R. Social Justice: The Moral Foundations of Public Health and Health Policy. Harris J, Holm S, Gillon R, Steinbock B, editors. Oxford. Oxford University Press; 2006. p. 10-28, 69-72.

15. Anderson MB. Do No Harm: How aid can support peace - or war. London: Lynne Rienner Publishers, Inc.; 1999. p. 2.

16. The Sphere Project. Humanitarian Charter and Minimum Standards in Humanitarian Response [Internet]. Practical Action Publishing; 2011 [cited 2014 Apr 13]. Available from: http://www. disaster-info.net/watermitigation/i/publications/Sphere/ hdbk_c2.pdf

17. Nussbaum MC. Creating capabilities. Cambridge. Belknap Press; 2011. p. 256.

18. Sen A, Nussbaum MC. The Quality of Life. Oxford: Clarendon Press; 1993. p. 30-53.

19. Daniels N. Just Health Care. Cambridge: Cambridge University Press; 1985. p. 245

20. Abrisketa J. The Right to Humanitarian Aid: Basis and Limitations. In: Unit HS, editor. Reflections Humanit. Action Princ. Ethics Contradict. London, Sterling, Virginia: Pluto Press; 2001. p. 69, 71.

21. Young H, Taylor A, Way S-A, Leaning J. Linking Rights and Standards: The Process of Developing "Rights-based" Minimum Standards on Food Security, Nutrition and Food Aid [Internet]. Disasters. Oxford: Blackwell Publishing; 2004. p. 142-59. [cited 2014 Apr 13]. Available from: http://content.ebscohost.com. ezproxy.liv.ac.uk/pdf13 15/pdf/2004/70S/01Jun04/13265917.pdf? $\mathrm{T}=\mathrm{P} \& \mathrm{P}=\mathrm{AN} \& \mathrm{~K}=15186361 \& \mathrm{~S}=\mathrm{R} \& \mathrm{D}=\mathrm{mnh} \&$ EbscoContent $=\mathrm{dGJyMM}$ 
vl7ESep7I4y9f30LCmr0qeprZSsaa4SK6WxWXS\&ContentCustome $\mathrm{r}=$ dGJyMOzprkmvqLJPuePfgeyx $43 \mathrm{zx}$

22. Slim H. Dissolving the Difference between Humanitarianism and Development: The Mixing of a Rights-Based Solution [Internet]. Dev. Pract. Taylor \& Francis Ltd. on behalf of Oxfam GB; 2000. p. 491-4 [cited 2014 Apr 13]. Available from: http://www.jstor.org. ezproxy.liv.ac.uk/stable/pdfplus/4029575.pdf?acceptTC=true

23. Dufour C, Geoffroy V de, Maury H, Grünewald F. Rights, Standards and Quality in a Complex Humanitarian Space: Is Sphere the Right Tool? [Internet]. Disasters. 2004. p. 124-41 [cited 2014 Apr 13] Available from: http://content.ebscohost.com.ezproxy.liv.ac.uk/ pdf13_15/pdf/2004/7QS/01Jun04/13265918.pdf?T=P\&P=AN\&K=1 $3265918 \& \mathrm{~S}=\mathrm{R} \& \mathrm{D}=\mathrm{a} 9 \mathrm{~h} \&$ EbscoContent=dGJyMNLr40Sep7M4y9f30 LCmr0qeprJSsam4S7SWxWXS\&ContentCustomer=dGJyMOzprkm vqLJPuePfgeyx $43 \mathrm{zx}$

24. UNHCR. Internally Displaced People On the Run in Their Own Land [Internet]. 2013 [cited 2013 Aug 25]. Available from: http://www. unhcr.org/pages/49c3646c146.html

25. Chung R, Hunt MR. Justice and Health Inequalities in Humanitarian Crises: Structured Health Vulnerabilities and Natural Disasters. In: Tamara P, Straehle C, editors. Heal. inequalities Glob. justice. Edinburgh University Press; 2012. p. 206.

26. Etxeberria X. The Ethical Framework of Humanitarian Action. In: Unit HS, editor. Reflections Humanit. Action Princ. Ethics Contradict. London, Sterling, Virginia: Pluto Press; 2001. p. 83.

27. Fuller L. Justified commitments? Considering resource allocation decisions and fairness in Medecins sans Frontieres-Holland. Dev. World Bioeth. 2006; 6(2): 59-70.

28. Hunt MR. Resources and constraints for addressing ethical issues in medical humanitarian work: Experiences of expatriate health care professionals. Am. J. Disaster Med. 2009; 4.5:261-72.

29. Loescher G, Milner J. Protracted Refugee Situations [Internet]. University of Oxford Refugee Studies Centre; 2012 [cited 2014 Apr 13]. Available from: http://www.prsproject.org/protracted-refugeesituations/

30. United States General Accounting Office GOA. Foreign affairs: Internally Displaced Persons Lack Effective Protection [Internet]. 2001 p. 3 [cited 2014 Apr 13]. Available from: http://content.ebscohost. com.ezproxy.liv.ac.uk/pdf17_20/pdf/2001/1EFG/17Aug01/18203712. pdf?T $=\mathrm{P} \& \mathrm{P}=\mathrm{AN} \& \mathrm{~K}=18203712 \& \mathrm{~S}=\mathrm{R} \& \mathrm{D}=\mathrm{buh} \&$ EbscoContent $=\mathrm{dGJy}$ MNHr7ESeprQ4y9f3OLCmr0qeprVSr624Sq6WxWXS\&ContentCust omer=dGJyMOzprkmvqLJPuePfgeyx $43 \mathrm{zx}$

31. ICRC. Protection of the civilian population [Internet]. 2010 [cited 2013 Aug 30]. Available from: http://www.icrc.org/eng/what we-do/protecting-civilians/overview-protection-civilian-population. htm
32. International Covenant on Economic S and CRI. Adopted and opened for signature, ratification and accession by General Assembly resolution 2200A (XXI), of 16 December 1966, entry into force 3 January 1976. Rights O of the UNHC for H, editor. 1976; Available from: http://www2.ohchr.org/english/law/cescr.htm

33. International Conference on Primary Health Care Alma-Ata. Declaration of Alma-Ata [Internet]. 1978 [cited 2013 Aug 30]. Available from: http://www.who.int/hpr/NPH/docs/declaration_almaata.pdf

34. UDHR. The Universal Declaration of Human Rights [Internet]. 1948 [cited 2013 Aug 30]. Available from: http://www.un.org/en/documents/udhr/index.shtml

35. Weijer C, Goldsand G, Emanuel EJ. Protecting communities in research: current guidelines and limits of extrapolation. Nat. Am. inc. [Internet]. 1999;23:275 [cited 2013 Aug 30]. Available from: http://www.unige.ch/medecine/ib/ethiqueBiomedicale/enseignement/programmeY2006/me-8-Emanuel-protecting-communitiesin-research.pdf

36. Society PHL. Principles of the Ethical Practice of Public Health [Internet]. 2002. Available from: http://www.apha.org/NR/ rdonlyres/1CED3CEA-287E-4185-9CBD-BD405FC60856/0/ethicsbrochure.pdf

37. IFRC. The Code of Conduct for the International Red Cross and Red Crescent Movement and NGOs in Disaster Relief [Internet]. 1995. p. 2-3 [cited 2013 Aug 30]. Available from: http://www.ifrc.org/ Docs/idrl/I259EN.pdf

38. OAU. African (Banjul) Charter on Human and People's Rights [Internet]. 1981 [cited 2013 Aug 25]. Available from: http://www1.umn. edu/humanrts/instree/z1afchar.htm

39. ICMP IC on MP. U.S. Helsinki Commission Hearing. Healing the wounds of conflict and disaster: Clarifying the fate of missing persons in the OSCE. Intervention by her Majesty Queen Noor, ICMP Commissioner [Internet]. 2012 p. 2 [cited 2013 Aug 30]. Available from: $\quad$ http://www.ic-mp.org/wp-content/uploads/2012/02/ icmp-dg-415-4-doc.pdf

40. BRCS. Restoring livelihoods after the tsunami [Internet]. 2013 [cited 2013 Aug 25]. Available from: http://www.redcross.org.uk/ What-we-do/Emergency-response/Past-emergency-appeals/ Boxing-Day-tsunami-2004/Restoring-lives-and-livelihoods

41. IFRC. Restoring livelihoods in Sri Lanka [Internet]. 2005 [cited 2013 Aug 28]. Available from: http://www.ifrc.org/ar/noticias/ noticias/asia-pacific/sri-lanka/restoring-livelihoods-in-sri-lanka/ 